\title{
Deconstructing diasporic mobilisation at a time of crisis: Perspectives from the Palestinian and Greek diasporas
}

\begin{abstract}
This paper focuses on the difficulties that diasporas face in relation to mobilising around helping the homeland at a time of crisis, using qualitative research on the Greek and Palestinian diasporas. Rather than assume that long-distance nationalism, emotional attachment to the homeland and diasporic obligation will galvanise diasporic populations into assisting, and mobilising around, the homeland, the paper argues that those in diasporas do not necessarily help their homelands in times of crisis, even if they have strong socio-cultural connections to it. At times of crisis these feelings are heightened but not do not always translate into direct action; this may especially be the case at times of prolonged crisis when past efforts to help do not seem to have worked. This paper argues that it is often hard for those in diaspora to find long-term and meaningful ways to help at a time of crisis and many question the effectiveness of their actions if they do not see positive outcomes over time. The paper demonstrates that trying to help the homeland can therefore be a frustrating process and can make those in diaspora feel distanced and isolated from the homeland due to their inability to find concrete ways to help. This can be especially the case when they have no formal political voice in the homeland and disagree with government policies and activities.
\end{abstract}

\section{Introduction}

A central aim of this paper is to add to the literature on diaspora mobilisation at times of crisis. In particular, it seeks to examine the disconnect between emotional attachments those members of a diaspora may have with a homeland and mobilisation. In other words, the paper will stress that despite having strong linkages to, and identification with, the homeland and a diasporic group, there is no guarantee that those in diaspora can be counted upon to mobilise and help their homeland at a time of crisis. It is this key contribution that the paper seeks to make, adding to what is already a rich amount of literature on diaspora mobilisation by exploring whether members of two diasporic groups, the Palestinian and the Greek, mobilise around two different types of crisis: conflict and statelessness for the former and economic for the latter, using qualitative research. It does, as the introduction to this special issue states (Koinova forthcoming), make a contribution to literature on theorisations and analyses of diaspora mobilisation in relation to contested sovereignty and fragile homeland states. It is not the aim of this paper to examine in detail the nature of these crises; they are being used as case studies to help demonstrate the importance of the temporal realities of diaspora mobilisation. What matters is that such crises elicit an emotional response for those in diaspora who feel attached to the homeland. Two questions then arise, which this paper seeks to address: do those in diaspora feel compelled to act, or to mobilise to help the 
homeland at a time of crisis? And if so, do they feel their actions are useful? In doing so, the paper discusses a potential disjuncture between strong feelings of diasporic identity and belonging on the one hand and weak diasporic mobilisation on the other.

Brinkerhoff $(2008,68)$ defines mobilisation as 'purposive action', and Müller-Funk $(2016,354)$ defines diaspora mobilisation as political activity which crosses one or more borders. The paper defines mobilisation in broad terms as 'helping' the homeland in material ways, be it through small acts of charity or taking in part in demonstrations, to everyday advocating in favour of a cause. Therefore, it focuses on what Koinova (2013) calls 'moderate contention' which are more established, less radical or extreme ways to mobilise, which can either be weak or strong. It is important to examine diaspora mobilisation, particularly in relation to long-distance nationalism and diasporic identity formation, as diasporic negotiations of home and belonging become ever more complex (Blunt 2007; Mavroudi 2007; Brinkerhoff 2016; Christou and Mavroudi 2015). Research on diaspora mobilisation needs to take into account these juxtapositions and examine the many different (dis)connections between here and there more closely and in inter-related ways, whereby diasporas are viewed as both transgressing and maintaining boundaries and borders (Brubaker 2005). In particular, there is a need to unpack the realities of diasporic action (or inaction) at times of crisis as well as the 'moral co-responsibility' and obligations of those in diaspora (Werbner 2002) which are based within people's everyday lives and social worlds (Page and Mercer 2012). Elite, as well as non elite members of a diaspora may choose to mobilise but may struggle to do so. It is these realities of (in)action and non mobilisation which this paper is concerned with. It examines how ordinary members of diaspora engage with mobilisation, and outlines the constraints and limitations which they feel they face. The next section of the paper provides a literature review on diaspora mobilisation, as well as a short description of the methods. Next, contextual information on both case studies is presented. The two case studies are then discussed separately, followed by a brief comparative analysis and conclusions.

\section{Deconstructing diaspora mobilisation}

Despite the potentially useful role that those in diaspora can play in mobilising for a homeland, questions remain about their ability, extent and willingness to do so (Beyene 2015). Whilst there are examples of positive effects on, for example, in terms of creating democracy in the homeland (Bernal 2006; Brinkerhoff 2012) some remain sceptical about the ability of those in diaspora to help the homeland at a time of crisis (Carter 2005; Cochrane 2007; Ǿstergaard Nielsen 2003; Anti-Boateng 2012) and others argue that context is important in such analyses (Shain 2002; Koinova 2011). Fiddian-Qasmiyeh (2013) stresses that many questions remain unanswered in terms of assumptions about diaspora involvement. She highlights that there is also a need to focus on individual members of diasporas more, rather than assume that 
those in diaspora act as a collective. We can extend these concerns and ask whether what tends to encourage or hinder diasporic mobilisation? Indeed, whilst there has been much research on diaspora mobilisation more broadly, there has been less on non-elite mobilisation (Fiddian-Qasmiyeh 2013) and on exactly how those in diaspora mobilise in relation to political struggles (Baser 2014; Madriaga Quinsaat 2016). There is therefore a need to unpack who is involved in diaspora mobilisation (Carter 2005; Kleist 2008; Yeh 2007; McConnell 2015), as well as the assumptions made about identities, obligations and diasporic activities (Faist 2008).

Despite the research which highlights how diasporas are able to respond to homeland crises (see Koinova 2011, for example), there is a need to more closely examine situations and contexts where diaspora mobilisation may be selective or limited. Brinkerhoff (2008) outlines the linkages between diasporic identity and mobilisation, stressing that there are specific factors which can aid mobilisation: shared social identity, dense and heterogeneous (ie non hierarchical) social networks and 'opportunity structures' (Esman 1986; also Müller-Funk 2016 on political opportunity structures prevalent in the host country as a factor). She goes on to discuss how motivation for mobilisation is linked to many factors such as a need to demonstrate or protect diasporic identity, organisational efficiency in framing a cause and demonstrating that action leads to impact and self-efficacy or feelings of empowerment. To this end, she argues that 'Self-efficacy combines with motivation to determine the likelihood of mobilization' (Brinkerhoff 2008, 77). Their identity plays a role because it can influence how they feel about their group solidarity and can help determine whether they feel it is worth mobilising on its behalf. Work has also shown how those in diaspora navigate obligations and expectations to mobilise and help the homeland at a time of crisis; for some this creates feelings of 'diaspora fatigue' (Shain and Barth 2003, 463), such as detachment, isolation, and guilt, which can translate into not wanting to mobilise or get involved in homeland affairs (Jones $2014)^{1}$. Shain and Barth $(2003,452)$ categorise members of diaspora into three groups:

(1) Core members are the organizing elites, intensively active in diasporic affairs and in a position to appeal for mobilization of the larger diaspora.

(2) Passive members are likely to be available for mobilization when the active leadership calls upon them.

(3) Silent members are a larger pool of people who are generally uninvolved in diasporic affairs but who may mobilize in times of crises.

They also divide diasporas into 'active' and 'passive' diasporas, the former influencing host and homeland policies, the latter not. They argue that for active diasporas to be successful, they need motive, opportunity and means. The homeland

\footnotetext{
${ }^{1}$ This stresses the need to examine more closely the emotions of diaspora mobilisation from the bottom up and at the micro-scale, which takes place within people's everyday lives. This stresses the grounded and situated nature of action and experience.
} 
and host society are seen as linked in the process. Mobilisation is perceived as more likely to occur if it is identity-reinforcing and where the right conditions occur in both the homeland and host country. The right conditions include ways to be politically active, integration, and host country attitudes towards the homeland and vice versa.

However, such categorisations and approaches imply that mobilisation occurs in an orderly, rational, predictable way, and that certain members of diaspora can always be relied upon to act (or not). In addition, it also seems to suggest that silent (and possibly passive) members are less likely to mobilise because of their lack of involvement in diasporic affairs. Research demonstrates how diaspora mobilisation itself is an active, potentially unstable, and needs to be learnt, created and negotiated (Page and Mercer 2012; Demir 2015).

The paper will engage with these issues using the case studies of diasporic Palestinians in Athens, and of Greeks in Australia. Both case studies are based on qualitative research comprising in-depth interviews with these two different diasporic groups with homelands facing different types of crisis. The first case study involved speaking to 54 members of the Palestinian diaspora in Athens, Greece and the research for this was carried out in 2003-2004 over a period of approximately 9 months. These were mostly first generation migrants who started arriving from the 1980 s onwards, thirty three of whom were men and twenty of whom were women ${ }^{2}$. The second case study was conducted in the early months of 2012 with members of the Greek diaspora in Canberra and Melbourne ${ }^{3}$. The two locations were chosen for the 'success' of their Greek communities. In total, 50 interviews were completed, with mainly first and second generation diasporic Greeks, 26 men and 24 women.

It should be stressed that these two pieces of research were not designed to be comparative and thus this paper is exploratory in nature. The paper uses the two case studies to discuss the hindrances to, and feelings towards, diaspora mobilisation, in relation to diasporic identity, belonging and attachment to the homeland. For both diasporic groups, as wide a cross-section of people were spoken to, especially in terms of socio-economic background; most were non-elite but the research also included some elites such as community and religious leaders. All interviews were conversational in style and used interview guides based around themes the researcher wished to explore. This created more freedom and flexibility for both researcher and participant and allowed for deeper discussion. All names appearing in the paper are pseudonyms in line with ethical considerations.

\footnotetext{
${ }^{2}$ For more on the different Palestinian 'groups' in Greece, see Shawa 2005.

${ }^{3}$ The Greek-Australian case study this paper is based on was funded by an Australian National University Centre for European Studies Visiting Fellowship.
} 


\section{Contexts}

\section{Palestinians in diaspora}

Palestinians have been living in diaspora since 1948 or what they call the year of the nakba (or catastrophe) and the creation of the state of Israel (Masalha 2008). They are dispersed mainly throughout the Middle East but also the rest of the world. It was only as a consequence (both directly and indirectly) of the 1967 Israeli occupation, the ensuing political turbulence and resistance, as well as the escalating discrimination towards Palestinians in some Arab countries that more large-scale migration to Europe began. According to the Palestinian Representation in Athens, at the time of research there were roughly 4000 Palestinians living in Greece.

The ongoing impasse in the Palestinian territories, the continued violence in the region, the lack of a territorially defined independent homeland state, and the disagreements around the Right of Return for Palestinian refugees constitute the main aspects of a cause which serves to unify and connect Palestinian in diaspora. It is these issues, which have been ongoing since 1948 and yet to be resolved, which galvanise diasporic Palestinian mobilisation, politicisation, long-distance nationbuilding and homeland-oriented politics in different contexts (Lindholm Schulz 2003) although their statelessness has also lead to disillusionment (Fiddian-Qasmiyeh 2016). However, within this, there is also the realisation that Palestinian cultural and political identities in diaspora are dynamic, potentially ambivalent and that Palestinians feel torn between here and there (Cox and Connell 2003; Mason 2007; Koinova 2014). In Greece, such commitment to the cause was evident, with strong feelings of 'Palestinan-ness' and close connections to the Palestinian territories and other places where Palestinians live in diaspora, such as Lebanon. However, their long-distance nationalism and need to mobilise around the cause needs to be unpacked and examined further, in order to ascertain the realities of mobilisation and helping the homeland at a time of prolonged crisis. One of the main issues related to this is the often lack of citizenship for Palestinians in Greece, and the accompanying lack of formal political rights both in Greece and in their homeland, which means that they do not have a formal political voice with which to be heard and use as part of their mobilisation. This is because of the ius sanguinis citizenship policy followed in Greece (Tsitselikis 2007) which makes it hard for non Greeks to attain Greek citizenship.

\section{Greeks in diaspora}

There is a long history of Greeks migrating with a dip in emigration in the early days of Greek independence when nation-building in the new state was seen as paramount (Prevelakis 1998). However, this changed after 1880 when new waves of Greek emigration began towards North and South America, Africa and Australia. The main period of emigration to Australia began after World War 2 rising to over 15,000 
by 1940 but it was after 1952 (until 1974) that over 250, 000 Greeks and Greek Cypriots made their way to Australia (Tamis 2005). Initially, most were male, uneducated and unskilled. It was only from the 1960s onwards that more female Greeks arrived and this generation aimed to permanently settle in Australia. Greeks in Australia are seen a 'success story' in the sense that they are perceived to have integrated into Australia, hold Australian citizenship and are able to participate fully in Australian cultural, political, social and economic life (Tamis 2005). Their relationship with the homeland has been one typified by connection. This is demonstrated by romanticisation of the homeland, strong feelings of belonging to Greece culturally, but also identities that are negotiated in fluid, and complex ways, especially in the second and third generations (Tamis and Tsolakis 1999; Tamis 2005; Tsolidis and Pollard 2010). Less is known about Greek diasporic economic connections and activities, which formed the starting point of this research. However, there are hints that Greeks in Australia could do more in terms of homeland-oriented business development and economic linkages with the homeland (Chrisodoulidis 2010; Hugo and Bakalis 2009; Hugo and Bakalis 2014). Given the economic crisis in Greece which began in 2008, there is a timely need for analysis on the role that the Greek diaspora can play in mobilising to help the homeland, particularly at a time of economic and political crisis (Hugo and Bakalis (2014).

The two contexts and groups are very different and this paper does not attempt to crudely and simplistically compare the two whilst glossing over important differences; rather, it is using these two diasporic groups in different locations at different times, using different crises to make some observations on the nature of diasporic mobilisation. It is not meant, nor was it designed as, a comparative study. The two pieces of work were conducted independently of eachother, but the methods used were similar. What holds for both diasporic groups is the attachment they feel towards their homeland and their feeling of belonging to their respective diasporas: this is a key shared variable which acts as a starting point for an exploration of their mobilisation to take place.

\section{Mobilising around a Palestinian cause in diaspora: from politicised identities to uncertainty}

Palestinians in Greece took part in some mobilisation activities based around support and advocacy of the cause, namely through demonstrations, cultural activities and support of charities helping Palestinians in the homeland. However, they also occasionally mobilised through more personal strategies such as ensuring children were raised as Palestinian. This section analyses the hindrances to such mobilisation and the feelings involved in doing so. In interviews, Palestinian participants displayed strong feelings of politicised Palestinian-ness, reminiscent of long-distance nationalism, whereby nation-building and the need to portray a unified and strategic Palestinian nation for the purposes of self-determination was evident. This occurred, in particular, through the choice of words used to express feelings and the fact that 
interviews were often emotionally laden, sometimes polemical in nature and imbued with a mixture of different, sometimes competing emotions. This included sadness at feelings of exile, and loss but also defiance and strength in terms of their ability to continue feeling Palestinian in diaspora. This is in line with other observations on Palestinian national identities in diaspora; for example, the Palestinian 'name' and national identity has been seen as being born in 'exile' (Said 1990, 360).

Such nation-building was linked to emotional feelings of belonging and attachment to the Palestinian territories, and to the Middle East more broadly. For Palestinians in Athens, such constructions of national identity appeared to be linked to the need to belong to a specific homeland or territory. As Heela ${ }^{4}$ stresses: 'everyone needs roots... your identity, where you belong is a very important aspect of your life, of who you are ... it defines you as a person'. Such views often went hand in hand with a need to rally around the injustice and suffering they felt Palestinians had endured, as well as a need to voice opinions about the cause, such as the loss of Palestinian territory and a Palestinian homeland:

From 1948, those who left then, they cannot go back. My father, when he left, he was 14,15 years old and he has been wounded by a Jewish bullet and so he remembers and he wishes so much that he could return to his wonderful country. This is why it is etched into our minds that this country is ours. We have to get it back because let's say you have your house with its rooms, kitchen and bathroom and someone comes with force and says I'm going to live and stay in your house now. I'm going to take these two rooms and the kitchen and you can have the toilet. Would you accept that seeing as the house is yours? You have to fight to get it back (lbrahim $\left.{ }^{5}\right)$.

Stories of exile were common, and were linked to the Palestinian cause, and the need for strategic and politicised unity in diaspora. Lina ${ }^{6}$, for example, describes how her family lost everything in 1948 and had to start from scratch. Her family story and the situation in the region have galvanised her politicisation: 'We have nothing left. I don't want to go until it's free land. I believe strongly that one day it will come back to us... they say in Arabic that blood never becomes water, so the land is built on the blood of the Palestinians'.

The need to secure a solution to the impasse, not just for themselves, but primarily for their children and future generations was a common feeling amongst participants and demonstrates commitment to mobilise for the Palestinian cause. Although many participants perceived a two state solution as a way forward, other participants were less sure what solution they were mobilising in favour of, even though they felt

\footnotetext{
${ }^{4}$ Office worker, female, from Jordan. Interview conducted in Athens, 13th January 2004, 8pm.

${ }^{5}$ Construction worker, male, from Safad. Interview conducted in Athens, 24th October 2003, 8pm.

${ }^{6}$ Businesswoman from Jaffa. Interview conducted in Athens, 15th December 2003, 5pm.
} 
politicised and that there was a need to try and do something to help the situation. This demonstrates how mobilisation for a cause can be rife with uncertainty, ambivalence, and helplessness over not only what outcome they are seeking, but also how to go about achieving it from afar. This is especially the case when the situation has been going on for so long; views and opinions change and people become disillusioned. As Maha ${ }^{7}$ explained, although she thinks 'it's very important for Palestinians to spread the word, to give the other side, our side of the story, it's very important, it's part of the struggle', she came to be uncertain as to what she wanted in terms of a solution. A large part of this stemmed from her emotional response to the situation there and it was clear she was visibly upset by the situation and her inability to know what to do about it:

I have 2 children and I don't want them to see this suffering. When I see the wall, when I see the people going through these checkpoints...[it is upsetting] I am one of the people [who didn't] want.. or thought that we could live in one state, as 2 peoples under one state but now I cannot see that, no way can I see that after this and I cannot see a state with $22 \%$ of the land, I cannot, because every time we ask, they ask more, every time we want, they want more, so with this, we cannot find a solution, we cannot.

Other respondents, such as Mustafa ${ }^{8}$, admitted that they felt they were more able to think about the situation there objectively as a result of the peace of mind they got from freedom of expression: 'You have to be open-minded and objective in order to understand all points of view and you know I learnt to be like this here. It's very hard to think openly and objectively there because you are so close to the problems, the stress'.

This highlights one of the benefits of being in diaspora, and of mobilising from afar in a country such as Greece, which has been sympathetic to the Palestinian cause and people, particularly when the left wing PASOK political party was in power in the 1980s (Agnantopoulos 2007). Initial impressions of constructions of Palestinian national identity may have emerged as being potentially narrow and 'unified' around the cause. However, further unpacking of their identities and opinions in diaspora revealed that many felt ambivalent about the merging of 'here' and 'there' and were also willing to think more openly and radically about the peace process, and to be tolerant of Jews. It also points to the dynamic nature of diasporic identities, opinions, and subsequently of mobilisation, which change over time and space.

For Palestinians in Athens, a factor influencing not just their opinions but their feelings about mobilisation, and their propensity to act, was their lack of formal political status: 'What can we do? We are not Greek citizens, so we cannot influence

\footnotetext{
${ }^{7}$ Housewife from Nablus. Interview conducted in Athens, 15th December 2003, 8pm.

${ }^{8}$ Unemployed male, from Hebron. Interview conducted in Athens, January 28th 2004, 9pm.
} 
the Greek government or politics. We are helpless here as foreigners; all we can do is tell people about the situation; this is very important' (Majid). ${ }^{9}$ So, despite the historical legacy of a pro-Palestinian Greek state, the inaccessibility of Greek citizenship made acting politically in a formal sense difficult and meant that participants had to rely on talking about their emotions, belonging and the situation in the Middle East to anyone who would listen, often within their everyday lives. This included speaking to Greeks, such as colleagues at work, other Palestinians in diaspora in each other's homes but also more forcefully in demonstrations, which some participants attended.

Others also felt that the Palestinian Authority (PA), set up after the Oslo Agreement in 1993 as a path to Palestinian governance, had not been concerned with the diaspora and they felt ignored, and even though they were keen to help their homeland, they found it hard to do so in formal political ways: 'Here we don't have the opportunity to affect what's going on there.... the fact that we cannot vote is a problem. They [the PA] don't care about Palestinians living outside Palestine and it is a big problem' (Faeq) ${ }^{10}$.

Many respondents also saw lack of time as a major restriction to engaging in advocacy and only those who were extremely politicised and committed to the cause and had the time, networks and financial resources were able to help on more than a superficial, occasional basis. This highlights the need to place diaspora mobilisation within the context of people's everyday lives (Page and Mercer 2012). The mundane realities of living in diaspora and coping on a day to day basis can be draining, especially when one factors in the guilt many feel that they are not there and suffering in the same way as Palestinians in the West Bank and Gaza. Diaspora mobilisation requires effort, which for some is simply too time consuming. Therefore, the extent to which Palestinians feel they are able to mobilise and help is dependent on personal factors such as financial and citizenship statuses.

Lina $^{11}$, despite the freedom she feels and the fact that does a great deal to help fellow Palestinians, outlines the fact that such help and advocacy is not straightforward. Thus, her perceptions of helping are both positive and negative: 'Palestinians who have money...don't have to think how to survive [but] others, they're worrying how to get money, to live, and then in their free time they participate, but in general...most of the Palestinians here are very close to each other...Many people would like to help'.

It is evident that she perceives that help begins in diaspora, assisting fellow Palestinians who are struggling. Her feelings of advocacy and 'helping' are dynamic

\footnotetext{
${ }^{9}$ Foreign Company Employee, male, from Safad. Interview conducted 11th November 2003, 8pm.

${ }^{10}$ Foreign Company employee, male, from Lebanon. Interview conducted in Athens, November 16th 2003, 10 am.

${ }^{11}$ Businesswoman from Jaffa. Interview conducted in Athens, 15th December 2003, 5pm.
} 
and hard to pin down, ranging from optimism, pessimism to guilt; this is neatly illustrated by the view she gives later on in the same discussion:

Yes, [it makes me feel helpless] I would like to put every month say one or two hundred euro to support one family there, because I can afford it but I'm not sure that this money would go to this family, you're never sure....

\section{I: Do you think that Palestinians here could do more?}

Lina: No. I believe that we should keep on trying or keep on supporting and when I said that there's always more we can do, I meant continuously, to continue support because really there are many Palestinian families who need supporting big time. And there is much more we could do politically, I suppose, although it's hard being here.

Therefore, there is uncertainty over how to mobilise and help fellow Palestinians, and over whether what they are doing is actually making any difference. This is not least because of factors such as the scale of poverty in the Palestinian territories and corruption as Lina above alludes to. This can make them feel apathetic, helpless and disillusioned. However, despite this, one must not assume that these people do not feel politicised or that they do not feel Palestinian. Their emotional connection to the homeland seemed to both galvanise and hinder their mobilisation. Therefore, there is a juxtaposition and disconnect between such feelings of politicised Palestinian identity, which were prevalent amongst participants, and the limited and often fragmented mobilisation many felt they could partake in. This does not prevent them from feeling Palestinian, politicised or from engaging in mobilisation. Even though it does appear that at times of specific need, many Palestinians in Athens are willing to actively help, there are severe limitations on this mobilisation if it has to be sustained over a lengthy period of time.

\section{Mobilising diasporic Greeks at a time of economic crisis}

The backdrop to this research was the Greek financial and political crisis which began in 2008, which is ongoing at the time of writing and has resulted in enormous debt and a crippled economy (for more on this see Karagiannis and Kondeas 2012). It was clear from the research conducted that the vast majority of participants felt a cultural affinity with Greece, and that, in line with other research on the Greek diaspora in different contexts, they felt this connection to be an emotional one (Christou 2011). The question that remains, however, is to what extent do these professed feelings of belonging to the homeland translate into concrete and material mobilisation at a time of crisis. For diasporic Greeks in Australia, such mobilisation around political and economic issues was decoupled from cultural attachment to Greece. For them, the economic and political crisis revolved around corruption, poor 
governance, challenging bureaucracy and an inefficient public sector. There was little sympathy for Greece's politicians and elites, and a pervading view that there was little they could do to help Greece at a time of economic crisis. However, if we unpack this further we see that many were cynical about their own mobilisation because of past negative experiences; this did not mean they did not want to help, but rather they felt it was often futile. This was linked to past experience of sending money, which was not then used to actually help people on the ground, which made them cynical and less likely to send money again. The views of Irini $^{12}$ are illustrative:

There is a general feeling of bitterness, like when there were a couple of earthquakes the Greek community generated hundreds of thousands of dollars to help with the relief. Not that any of the money went to the people that needed it as we subsequently found out but we did our bit...so I think that has made people a bit weary. There'll still be efforts and assistance but I do think there's a general feeling of well is the money going to get there?

There is clearly willingness to help during times of crisis, as the quotes demonstrate. However, they also show the realities people face when trying to help, and their frustration with corruption and bureaucracy, especially when they compared it to the context in Australia which they were used to and felt was more organised, more transparent, less bureaucratic and was better governed. Even if people want to help at a time of crisis, and feel obligated to, trust can be issue, and they may struggle to find the best way to help:

So with the fires, we were quite happy [to help] but we sent the money through the International Red Cross because we knew if it went to someone Greek, you know where would the money go? Their biggest problem is themselves and I believe that if they were trustworthy they wouldn't be having a problem right now, the Greeks outside of Greece would have helped them out already ${ }^{13}$.

$\mathrm{XXX}$

I feel that we have a moral obligation to help in some way. How we do that is a difficult question. Last year or the year before they asked the ten richest Greek business men if they would send money back to Greece. And most of them didn't bother answering, but some of them did say 'no', because they have seen the Greeks waste the money ${ }^{14}$.

Their experiences of living in Australia, where economic and political systems were perceived to be more transparent, professional, and less corrupt also seemed to influence their cynicism about mobilisation and their perceptions of the situation in Greece. From the quotes above, there is also a clear division being drawn between

\footnotetext{
${ }^{12}$ Female, second generation. Interview conducted 31st January 2012, 10am, in Melbourne.

${ }^{13}$ Alexi, second generation male. Interview conducted in Canberra, 16th January 2012, $11 \mathrm{am}$.

${ }^{14}$ Yiorgos, second generation male. Interview conducted in Canberra, 27th January 2012, 2pm.
} 
'us' (in Australia) and 'them' (in Greece) and there is a feeling that they are different. Clearly there is a need to critique any assumptions about the extent to which those in diaspora share views, perceptions and identities with those in the homeland. Those in diaspora are not simply an extension of those in the homeland, on whom homeland governments can blindly depend on, or engage with at will. The emotional connections that those in diaspora may feel towards their homeland can co-exist alongside disconnections, disillusionment and apathy. However, these emotional connections can also lead to sympathy and compassion for those suffering in the homeland and frustration and guilt that there is little they feel they can do to help especially when they see that things do not change for the better over time:

Most people don't really want [to help]. They think often that it serves Greeks right because of the shocking practices of governments in the last 30, 40, 50 years. People who have gone over get frustrated at how cumbersome and bureaucratic the system is and feel [the crisis] was long time coming. People can make connections to their family, and even there you think up to a point and how am I going to help?... The concept of Greece is just another idea which grows more distant - why would you really care that much, alright yes, your heritage is there and stuff like that but you don't really connect with it , because you're hardly ever there ${ }^{15}$.

This quote also stresses the issue of distance and disconnection. Although we may assume that those in diaspora are always connected to their homeland, the reality is that people cannot physically be in two places at the same time even if they are emotionally and everyday life in one's country of residence takes over, especially if they are not able to visit the homeland often. The fact that they cannot help even though they might want to, coupled with Australian perceptions of Greece can be hard to deal with and can create defensiveness against ridicule: 'It hurts me that Greece is going through this because ...the country is being ridiculed... you know you can criticise your own family but when the outsider criticises it, it's not on ${ }^{16}$. Clearly, he feels connected to Greece despite living so far away but this emotional attachment can make things harder when they feel they cannot help in any meaningful way. This, rather than galvanise activity, can subdue it and make people 'switch off' and lack confidence, as Dimitri ${ }^{17}$ says:

I think if people here could, they would like to be able to help but I feel that not too many willing to go and say how can I help? Because they don't have the confidence to say OK we'll come and help you - but is that going to help you in the long term? A lot of money was poured into Greece [in the past] to help improve standards.. I don't think it was utilised in the proper way.

\footnotetext{
${ }^{15}$ Christos, second generation male. Interview conducted in Melbourne, 18th January 2012, 11 am

${ }^{16}$ Christos, second generation male. Interview conducted in Melbourne, 18th January 2012, 11am

${ }^{17}$ Dimitri, first generation male. Interview conducted in Canberra, 2nd February 2012, 4pm.
} 
For diasporic Greek participants in Australia, mobilisation often manifested itself in helping family and in personal ways, where there was more trust and there were more assurances that the money would be spent properly and would actually be useful. Many felt there were few incentives to help in other ways and that the bureaucratic and corrupt systems in Greece meant that investment in enterprise was limited, and that helping charities was also problematic for these reasons. Although, as work has commented (Hugo and Bakalis 2009; Hugo and Bakalis 2014), there appears to be the potential for stronger economic linkages between Greece and Australia, which could theoretically be used at a time of crisis, this potential was not being realised.

\section{Different contexts, similar feelings towards mobilisation? A brief comparison}

The paper has demonstrated that in terms of predicting diasporic mobilisation, it does not matter whether those in diaspora are citizens or not of the host or homeland, whether the homeland is a state, or not, whether there are strong organisational and social networks, whether a crisis is economic or political. Such factors, which are stressed in the diaspora mobilisation literature, do not seem to be important in these two case studies. Both Greece and Australia provide seemingly good contexts for diaspora mobilisation in terms of dense social networks and diasporic leadership. Certain themes also cross-cut both case studies: the length of the crisis and how protracted it is; uncertainty about how best to help; and related to this, trust and perceptions of corruption in the homeland. For both groups, there was ambivalence about their mobilisation during the crises under exploration. This appeared to stem from their strong feelings of emotional attachment to the homeland. This connection meant they did care about their homeland and 'ordinary' people caught up in crisis, but they often felt guilty and disillusioned because they did not know how best to help them. The only context that seems to matter is the homeland: in both case studies, participants felt attached emotionally and culturally to it and they were affected by homeland crises and this led them to consider mobilising. However, the realities of helping 'on the ground' were often difficult in both case studies.

This serves as a reminder that the motivation and the means to mobilise are both needed. What linked both case studies was an abundance of the former but a lack of the latter; 'diaspora fatigue' (Shain and Barth 2003, 463) was also present for both because the crisis for both groups is ongoing, and because of a lack of trust in the outcome and impact of diaspora mobilisation attempts. Rather than being galvanised by a crisis, both groups struggled with disillusionment and apathy. However, this did not mean that they were any less connected emotionally or culturally to their homeland. To go back to Brinkerhoff (2008) who argued that people in diaspora are more likely to mobilise if they can see a positive outcome, this holds true. However, she also argued that mobilisation is also centred around identity protection. The participants in the two case studies were seemingly concerned with promoting their diasporic identity, and were proud of it. However, rather than this automatically 
galvanising action, whether or not they mobilised depended on their own personal feelings of empowerment, their trust in whether their mobilisation attempts were useful and/or subject to corruption and inefficiency. All these factors, it is important to stress again, did not seem to impact on their feelings of strong diasporic identity. In other words, any feelings of apathy or disillusionment in terms of mobilisation did not translate back into negative perceptions of diasporic identity and belonging. This means that there is always the potential for them to wish to mobilise, and in the future, to mobilise more successfully, if their feelings of trust increase, or if they can find more effective ways to mobilise. Indeed, it was also apparent that rather than being rational actors who sought to maximise their position and ability to help their homeland, the ways in which they talked about their mobilisation highlighted the messy nature of diaspora mobilisation.

\section{Conclusions}

This paper has contributed to the literature on diaspora mobilisation by demonstrating a disjuncture between strong emotional belonging to the homeland and mobilisation. In other words, such belonging does not guarantee action and we cannot assume there will be automatic mobilisation by people who feel part of a diaspora and deeply linked to a homeland. This paper has explored the disconnect and disjuncture between professed diasporic identity and connections to the homeland, on the one hand, and the realities of weak, ineffective or nonexistent diasporic mobilisation, and of limitations and constraints to such mobilisation at times of crisis, on the other. Strong diasporic identities are therefore not necessarily a precursor to, or a springboard for, mobilisation.

This paper suggests that those in diaspora often appear to feel disillusioned by their attempts to help the homeland at a time of crisis even when there are many factors which provide the 'right' conditions for mobilisation, such as motivation, and strong identity. The means to mobilise also existed in both contexts but participants did not necessarily find them satisfactory or trustworthy. Context in this paper, as the introduction to this special issue highlights (Koinova, forthcoming), matters because the issue of time is important for both diasporas and both crises. The length and timing of the homeland crisis affected those in diaspora and their propensity to mobilise. Although it has been noted that diaspora engagement with the homeland is a 'craft' to be learnt (Page and Tanyi 2015), this process of learning is one of trial and error and not necessarily easy. Not only does it take time, but potentially occurs in peaks and troughs, or not at all. More attention arguably needs to be paid to the timespace of diaspora mobilisation (and migration more generally) as the introduction to this special issue stresses (Koinova, forthcoming; also see Mavroudi, Page and Christou forthcoming).

This suggests that diaspora mobilisation can be hard to categorise and predict because it can depend on a mixture of deep feelings such as hope and loyalty (which 
can lead to mobilisation) as well as despair and guilt (which can lead to a lack of mobilisation) and people have many different feelings. In other words, people may feel conflicted and have changeable thoughts about mobilisation. To categorise them as either 'passive', 'silent' or 'active' (Shain and Barth 2003) ignores the complexity of their feelings and how they may slip between such groupings over time and space. This is also linked to their complicated, multiple, flexible identities and feelings of belonging, which are often hybrid, ambivalent and 'hard to pin down'. This stresses the importance of emotions in research on diasporic identity (Christou 2011), which arguably needs more attention in the literature on diaspora mobilisation.

This paper also reminds us that homeland governments cannot necessarily rely on the support or help of diasporas, which needs to be considered in potential diaspora strategies (Ho 2015; Larner 2007; Jöns, Mavroudi and Heffernan 2015). At times of crisis, in weak states and regions where sovereignty is contested, governments and those in positions of power, such as diasporic leaders and activists, need to do more to win over the trust of those in diaspora, in order to demonstrate that actions yield some sort of results, even small, incremental ones. Although diasporas undoubtedly can help their homelands in positive ways at a time of crisis, more research is needed to uncover the limitations and opportunities in relation to such activity.

\section{References}

Antwi-Boateng, O. 2012. "After War then Peace: The US-based Liberian Diaspora as Peace-building Norm Entrepreneurs". Journal of Refugee Studies 25: 93112.

Baser, B. 2014. "The Awakening of a Latent Diaspora: The Political Mobilization of First and Second Generation Turkish Migrants in Sweden". Ethnopolitics 13(4): 355-376.

Bernal, V. 2006. "Diaspora, Cyberspace and Political Imagination: The Eritrean Diaspora Online". Global Networks 6(2): 161-179.

Beyene, H.G. 2015. "Are African diasporas development partners, peace-makers or spoilers? The case of Ethiopia, Kenya and Nigeria". Diaspora Studies 8 (2): 145-161.

Blunt, A. 2007. "Cultural Geographies of Migration: Mobility, Transnationality and Diaspora". Progress in Human Geography 31: 684-694.

Brinkerhoff, J.M. 2016. Institutional Reform and Diaspora Entrepreneurs: The inBetween Advantage. Oxford: Oxford University Press. 
Brinkerhoff, J.M. 2012. "Creating an Enabling Environment for Diasporas'

Participation in Homeland Development". International Migration 50: 75-95.

Brinkerhoff, J.M. 2008. "Diaspora Identity and the Potential for Violence: Toward an Identity-Mobilization Framework". Identity 8 (1): 67-88.

Brubaker, R. 2005. "The "Diaspora" Diaspora". Ethnic and Racial Studies 28: 1-19.

Carter, S. 2005. "The Geopolitics of Diaspora". Area 37(1): 54-63.

Chrisodoulidis, N. 2010. I Ikonomia stin Afstralia ke i eborikes ke ikonomikes shesis Ellada-Afstralia 2009 (The economy in Australia and the trade and economic relations between Greece and Australia 2009), Office of Greek Economic and Trade Affairs, Sydney, Australia (in Greek).

Christou, A. and E. Mavroudi, eds 2015. Dismantling diasporas: rethinking the geographies of diasporic identity, connection and development. London: Ashgate.

Christou, A. 2011. "Narrating Lives in (E)motion: Embodiment, Belongingness and Displacement in Diasporic Spaces of Home and Return". Emotion, Space and Society 4: 249-257.

Cochrane, F. 2007. "Civil Society Beyond The State: The Impact of Diaspora Communities on Peace Building". Global Media Journal: Mediterranean Edition 2: 1929

Cox, J., and J. Connell. 2003. "Place, Exile and Identity: the Contemporary Experience of Palestinians in Sydney". Australian Geographer 34(3): 329-343.

Demir, I. 2015. "Battlespace Diaspora: How the Kurds of Turkey Revive, Construct and Translate the Kurdish Struggle in London", in Dismantling Diasporas: Rethinking the Geographies of Diasporic Identity, Connection and Development, edited by Christou, A. and E. Mavroudi, 71-85. London: Ashgate.

Esman, M. J. 1986. "Diasporas and international relations", in Modern diasporas in international politics, edited by G. Sheffer, 333-349. London: Croom Helm.

Faist, T. 2008. "Migrants as Transnational Development Agents: An Inquiry into the Newest Round of the Migration-Development Nexus". Population, Space and Place 14: $21-42$.

Fiddian-Qasmiyeh, E. 2016. "On the Threshold of Statelessness: Palestinian Narratives of Loss and Erasure". Ethnic and Racial Studies 39 (2): 301-321. 
Fiddian-Qasmiyeh, E. 2013. "Transnational Childhood and Adolescence: Mobilizing Sahrawi Identity and Politics across Time and Space". Ethnic and Racial Studies 36 (5): 875-895.

Ho, E., M. Hickey and B.S.A Yeoh. 2015. "Special Issue Introduction: New Research Directions and Critical Perspectives on Diaspora Strategies". Geoforum 59: 153-158.

Hugo, G. and S. Bakalis. 2014. "Rethinking The Role of The Diaspora as a Key Part of a Development Strategy for Greece". Paper for Conference on The Greek economy from crisis to development, 4-5 April 2014, Volos, Greece. Available online at:

http://www.seedcenter.gr/conferences/Crisis2014/papers/Hugo\%20Bakalis_rethinkin g\%20the\%20role\%20of\%20the\%20diaspora\%20as\%20a\%20key\%20part\%20of\%20 a\%20development\%20strategy\%20for\%20greece.pdf [last accessed 19th June 2016]

Hugo, G., and S. Bakalis 2009. "The Potential of Hellenic-Australian Diaspora Entrepreneurial Networks", in Greek Research in Australia: Proceedings of the Biennial International Conference of Greek Studies, edited by E. Close, G. Couvalis, G. Frazis, M. Palaktsoglou, and M. Tsianikas, 215-232. Flinders University, Flinders University Department of Languages - Modern Greek: Adelaide.

Jöns, H., E. Mavroudi, E. and M. Heffernan. 2015. "Mobilising the Elective Diaspora: German-American academic Exchanges in the Postwar Period". Transactions of the Institute of British Geographers 40 113-127

Jones, D. 2014. "Diaspora Identification and Long-distance Nationalism among Tamil Migrants of Diverse State Origins in the UK". Ethnic and Racial Studies 37(14): 2547-2563.

Karagiannis, N. and A.G. Kondeas. 2012. "The Greek Financial Crisis and a Developmental Path to Recovery: Lessons and Options". International Journal of Business and Social Science 3 (13), available online at http://ijbssnet.com/journals/Vol_3_No_13_July_2012/3.pdf, last accessed 19th June 2016.

Kleist, N. 2008. "Mobilising 'The Diaspora': Somali Transnational Political Engagement". Journal of Ethnic and Migration Studies 34: 307-323.

Koinova, M. 2017. "Diaspora Mobilization for Conflict and Postconflict Reconstruction: Contextual and Comparative Dimensions," Journal of Ethnic and Migration Studies, forthcoming. 
Koinova, M. 2014. "Why Do Conflict-Generated Diasporas Pursue SovereigntyBased Claims Through State-based or Transnational Channels? Armenian, Albanian and Palestinian diasporas in the UK Compared". European Journal of International Relations 20:4 1043-1071.

Koinova, M. 2013. "Types of Diaspora Mobilization: Albanian diaspora Activism for Kosovo Independence in the US and the UK". Foreign Policy Analysis 9: 433-453.

Koinova, M. 2011. "Diasporas and Secessionist Conflicts: The Mobilization of the Armenian, Albanian and Chechen Diasporas". Ethnic and Racial Studies 34(2): 333356.

Larner, W. 2007. "Expatriate Experts and Globalizing Governmentalities: The New Zealand Diaspora Strategy". Transactions of the Institute of British Geographers (32): 331-345.

Lindholm Schulz, H. 2003. The Palestinian diaspora: Formation of identities and politics of homeland. London: Routledge.

Madriaga Quinsaat, S. 2016. "Diaspora Activism in a Non-Traditional Country of Destination: the Case of Filipinos in the Netherlands". Ethnic and Racial Studies 39 (6):1014-1033.

Masalha, N. 2008. "Remembering the Palestinian Nakba: Commemoration, Oral History and Narratives of Memory". Holy Land Studies 7 (2): 123-156.

Mason, V. 2007. "Children of the "Idea of Palestine": Negotiating Identity, Belonging and Home in the Palestinian Diaspora". Journal of Intercultural Studies 28: 271-285.

Mavroudi, E., B. Page and A. Christou, eds forthcoming. Timespace and international migration. Cheltenham: Edward Elgar.

Mavroudi, E. 2007. "Learning to be Palestinian in Athens: Constructing Diasporic National Identities". Global Networks, 7 (4): 392-412.

McConnell, F. 2015. "Reconfiguring Diaspora Identities and Homeland Connections: The Tibetan 'Lhakar' Movement" in Dismantling Diasporas: Rethinking the Geographies of Diasporic Identity, Connection and Development, edited by Christou, A. and E. Mavroudi, 99-113. London: Ashgate.

Müller-Funk, L. 2016. "Diaspora Mobilizations in the Egyptian (Post)Revolutionary Process: Comparing Transnational Political Participation in Paris and Vienna", Journal of Immigrant and Refugee Studies 14 (3): 353-370. 
Ǿstergaard-Nielsen, E. 2003. "The Democratic Deficit of Diaspora Politics: Turkish Cypriots in Britain and the Cyprus issue". Journal of Ethnic and Migration Studies 29: 683-700.

Page, B. and C. Mercer. 2012. "Why Do People Do stuff? Reconceptualising Remittance Behaviour in Diaspora-development Research and Policy". Progress in Development Studies 12: 1-18.

Page, B. and R. Tanyi. 2015. "Engaging the African Diaspora in the Fight Against Malaria", in Dismantling Diasporas: Rethinking the Geographies of Diasporic Identity, Connection and Development, edited by Christou, A. and E. Mavroudi, 189-203. London: Ashgate.

Prevelakis, G. 1998. "Finis Greciae or The Return of the Greeks? State Diaspora in the Era of Globalisation". Transnational Communities Programme, School of Geography, University of Oxford Working Paper, available at http://www.transcomm.ox.ac.uk/working\%20papers/prevelakis.PDF, last accessed 19th June 2016.

Said, E. 1990. "Reflections on exile", In Out there, marginalization and contemporary cultures edited by R. Ferguson, M. Gever, T. Minh-ha and C. West, 357-366. Cambridge MA: MIT Press.

Shain, Y. 2002. "The Role of Diasporas in Conflict Perpetuation or Resolution". SAIS Review of International Affairs 22: 115-144

Shain, Y. and A. Barth. 2003. "Diasporas and International Relations Theory". International Organization 57:449—479.

Shawa, S. 2005. "Palestinians in Greece: Same Sense of Belonging, Diverse Communities", in The Palestinian diaspora in Europe: Challenges of dual identity and adaptation, edited by A. Shiblak. Shaml (The Palestinian Refugee and Diaspora Centre) and the Institute of Jerusalem Studies. available online at <http://www.rsc.ox.ac.uk/PDFs/Shiblak.pdf>, last accessed 19th June 2016.

Tamis, A.M. 2005. The Greeks in Australia. Cambridge: Cambridge University Press.

Tamis, A.M., and D. Tsolakis, D. 1999. The History of Greeks of Canberra and Districts. Melbourne: NCHSR. 
Tsitselikis, K. 2007. "Citizenship in Greece: Present Challenges for Future Changes", in Multiple Citizenship as a Challenge to European Nation-States, edited by D. Kalekin-Fishman and P. Pitkanen, 145-170. Rotterdam: Sense publishers.

Tsolidis, G. and V. Pollard. 2010. "Home Space: Youth Identification in the Greek Diaspora". Diaspora, Indigenous, and Minority Education: Studies of Migration, Integration, Equity, and Cultural Survival 4 (3): 147-161.

Werbner, P. 2002. "The Place which is Diaspora: Citizenship, Religion and Gender in the making of Chaordic Transnationalism". Journal of Ethnic and Migration Studies 28(1): 119-133.

Yeh, E.T. 2007. "Exile Meets Homeland: Politics, Performance, and Authenticity in the Tibetan Diaspora". Environment and Planning D: Society and Space 25: 648-667. 